\title{
POLA PERGERAKAN PEMBELI TERHADAP TATA LETAK PEDAGANG KAKI LIMA DI PASAR SUMUR BATU JAKARTA PUSAT
}

\author{
Ni’mal Maulana Rizqi ${ }^{1}$, Putra Fajar ${ }^{2}$, Taslim Septia Prima ${ }^{3}$, Dedi Hantono ${ }^{4}$ \\ 1,2,3,4 Program Studi Arsitektur, Universitas Muhammadiyah Jakarta, Jl. Cempaka Putih Tengah 27, \\ Jakarta Pusat, Indonesia \\ e-mail: dedihantono@umj.ac.id ${ }^{1}$
}

How to cite (in APA style):

Hantono, D., Rizqi, N. M., Fajar, P. \& Prima, T. S. (2020). Pola Pergerakan Pembeli Terhadap Tata Letak Pedagang Kaki Lima Di Pasar Sumur Batu Jakarta Pusat. Undagi: Jurnal Ilmiah Jurusan Arsitektur Universitas Warmadewa. 8 (1), pp.1-9.

\begin{abstract}
Sumur Batu Market is a growing market because of the existence of a modern market that is too far away. This market has many street vendors because of its busy location at night. The difference in sellers in the morning to evening and evening to night makes this market interesting to study. This happens because the traders who trade in the two different times and the movement of the people towards the two different times. The research to be carried out is carried out using personal observation, giving rise to documentation that is communicated in design and textually. The results of this study will bring up the results of the analysis of the zoning of traders that affect the pattern of buyer movement, both of which will provide its own advantages and disadvantages, especially in causing congestion on the road that causes congestion.
\end{abstract}

Kata kunci: Activity, Market Circulation, Street Vendors, Informal Market.

\begin{abstract}
ABSTRAK
Pasar Sumur batu merupakan pasar yang tumbuh karena keberadaan pasar modern yang terlampau jauh. Pasar ini memiliki banyak pedagang kaki lima karena lokasinya yang ramai saat malam hari. Perbedaan penjual pada pagi hingga sore dan sore hingga malam membuat pasar ini menarik untuk diteliti. Ini terjadi karena pedagang yang berdagang di kedua waktu tersebut yang berbeda dan pergerakan masyarakat terhadap kedua waktu tersebut yang berbeda pula. Penelitian yang akan dilakukan dilaksanakan dengan menggunakan pengamatan pribadi, sehingga menimbulkan dokumentasi yang dikomunikasikan secara desain dan tekstual. Hasil dari penelitian ini akan memunculkan hasil analisis terhadap zonasi pedagang yang berpengaruh kepada pola pergerakan pembeli, yang mana keduanya akan memberikan keuntungan dan kerugian tersendiri terutama dalam menimbulkan kepadatan pada jalan yang menyebabkan kemacetan.
\end{abstract}

Keywords: Aktivitas, Sirkulasi Pasar, Pedagang Kaki Lima, Pasar Informal.

\section{PENDAHULUAN}

Pasar sebagai pusat aktivitas jual-beli yaitu tempat bertemunya para penjual dan pembeli (Damsar \& Indrayani, 2018). Seiring dengan waktu pasar menjadi tempat yang semakin ramai baik oleh pedagang maupun pembeli. Kegiatan ini telah berlangsung sejak lama dan masih melekat pada kebiasaan masyarakat dalam melakukan kehidupannya sehari-hari. Dengan keberadaannya yang kian ramai banyak sekali dimanfaatkan oleh pedagang tidak tetap untuk mencari hasil di tempat tersebut salah satunya adalah pedagang kaki lima.

Pedagang kaki lima adalah pedagang yang menggunakan gerobak berkaki lima sebagai media dalam melakukan transaksi jual beli. Pedagang kaki lima hanya menjual satu atau dua jenis barang dagangan dengan menggunakan gerobak yang dapat berpindah tempat dari satu ke tempat yang lain dengan mendorong gerobak menuju lokasi tersebut. Biasanya pedagang kaki lima termasuk pedagang tidak tetap pada suatu pasar. 
Pengaruh terhadap keberadaan pedagang kaki lima sering membuat berbagai macam permasalahan terutama dalam menggunakan lahan untuk melakukan transaksi jual beli. Tak banyak pula yang menggunakan bahu jalan sebagai tempat melakukan transaksi jual beli sehingga mengganggu lalu lintas kendaraan. Dengan keberadaannya para pembeli rela harus memarkirkan kendaraannya di bahu jalan agar dapat bertransaksi jual beli dengannya. Dalam suatu daerah pasar terdapat berbagai macam pedagang kaki lima yang terletak secara acak sehingga para pembeli harus berputar-putar bahkan harus kembali ke posisi awal untuk mendapatkan barang yang diinginkan.

Adapun Masalah yang diidentifikasi adalah sebagai berikut:

1. Bagaimana pola pergerakan pembeli terhadap pedagang kaki lima di pasar Sumur Batu?

2. Bagaimana zonasi tipe pedagang kaki lima di pasar Sumur Batu?

Tujuan dari penelitian ini adalah sebagai penambah wawasan perihal pola pergerakan pembeli pasar dan zonasi pedagang kaki lima yang ada di pasar sumur batu yang mana bisa dijadikan rujukan dalam menuntaskan suatu permasalahan yang ada atau dapat menjadi acuan dalam pengembangan pasar yang lebih baik lagi.

\section{METODE PENELITIAN}

Metode penelitian ini menggunakan metode kualitatif. Metode kualitatif sendiri adalah metode yang menitikberatkan pada sebuah deskripsi, analisis dan wawancara yang mana deskripsi dan analisis ini dapat diteliti menggunakan indera penglihatan. Metode ini pun didukung oleh teori-teori yang berhubungan dengan penelitian ini agar penelitian semakin meyakinkan dan terarah.

Lang (1987) mengemukakan penelitian yang dilakukan dengan pendekatan kualitatif dapat melalui pengamatan dan pemetaan perilaku (behavior mapping) untuk mengetahui pola aktivitas seseorang. Metode analisis deskriptif dilakukan untuk memperoleh pengunaan ruang berdasarkan pola aktivitas seseorang. Dibutuhkan beberapa variable untuk menganalisa penelitian ini, diantaranya:
1. Perilaku, yaitu seseorang yang menjadi objek dan menggunakan fasilitas pasar dengan tujuan berbelanja.

2. Aktivitas, yaitu kegiatan yang dilakukan oleh pengguna di pasar

3. Alur, yaitu pola gerak dari objek yaitu pedagang dan konsumen di sepanjang jalan pasar sumur batu.

4. Waktu, yaitu pengamatan secara langsung diakukan di sore hari dan malam hari karena secara aktivitas pasar informal ini terjadi keramaian pada saat pulang kantor dan malam hari.

5. Bentuk, yaitu: tempat yang dijadikan objek penelitian Pasar Sumur Batu

\section{Persiapan Pengumpulan Data}

Dalam melakukan penelitian diperlukan datadata sebagai pendukung untuk persiapan yang baik, diantaranya:

1. Menetapkan Batasan penelitian: lokasi, perilaku, peristiwa, dan proses

2. Strategi penelitian: pengamatan, dokumentasi, dan visual.

\section{Merencanakan Penelitian}

Berkunjung untuk membeli sesuatu sembari megamati keadaan sekitar agar pengamatan tidak menimbulkan kecurigaan dan berperilaku tidak terlalu mencuri perhatian seolah sedang melakukan penelitian.

Beberapa hal yang menjadi penekanan dalam penelitian diantaranya: perilaku, aktivitas, alur, dan waktu.

Waktu penelitian dilakukan di hari awal pekan dan hari akhir pekan untuk membedakan perubahan yang signifikan mengenai objek penelitian. Penelitian dilakukan dari bulan September sampai dengan Desember.

\section{Melakukan Penelitian}

Penelitian dilakukan sesuai dengan rencana penelitian. Rencana penelitian yang sudah dipersiapkan yaitu mencari beberapa data yang penting dengan mengamati keadaan sekitar sepanjang hari dan mendokumentasikannya. Lalu hasil dari penelitian tersebut di analisis sehingga menghasilkan kesimpulan yang terpadu. 


\section{Menganalisis hasil Penelitian}

Analisis penelitian dilakukan dengan cara mengolah data yang sudah di dapat agar dapat menghasilkan faktor faktor yang dibutuhkan. Analisis tersebut didukung dengan penerapan desain 2 dimensi sebagai alat komunikasi yang dapat dimengerti oleh segala pihak. Setelah itu hasil dari analisis diberi kesimpulan yang sesuai dengan hasil analisis.

\section{Memberi Kesimpulan}

Kesimpulan diambil melalui hasil analisis yang menjawab rumusan masalah dari penelitian. Yang mana kesimpulan ini menjadi sebuah hasil yang mencakup seluruh kegiatan penelitian yang ada.

\section{HASIL DAN PEMBAHASAN}

\section{Kondisi Umum Pasar Sumur Batu}

Pasar sumur batu terletak di kota Jakarta Pusat yang mana berada pada kecamatan Kemayoran tepatnya di jalan sumur batu raya. Pasar ini telah berdiri sejak lama sehingga menjadi pasar yang sudah ramai dikunjungi warga sekitar. Ini terjadi karena posisi dari pasar ini yang strategis dan berdiri di tengah tengah kekosongan pasar modern seperti pada gambar di bawah ini.

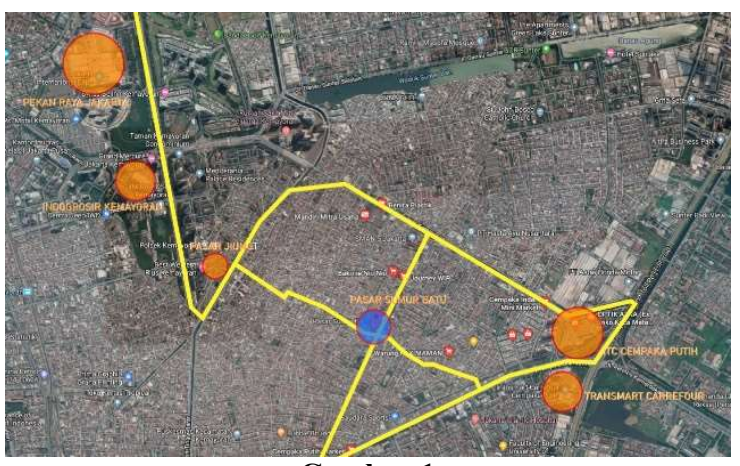

Gambar 1

Posisi Pasar Sumur Batu

(Sumber: Google Maps dan Olah Pribadi, 2019)

Lingkaran biru adalah posisi pasar sumur batu dan lingkaran jingga adalah posisi pasar pasar modern. Sehingga pasar ini memudahkan masyarakat dalam mencari barang barang kebutuhan rumah tangga dan lain lain.

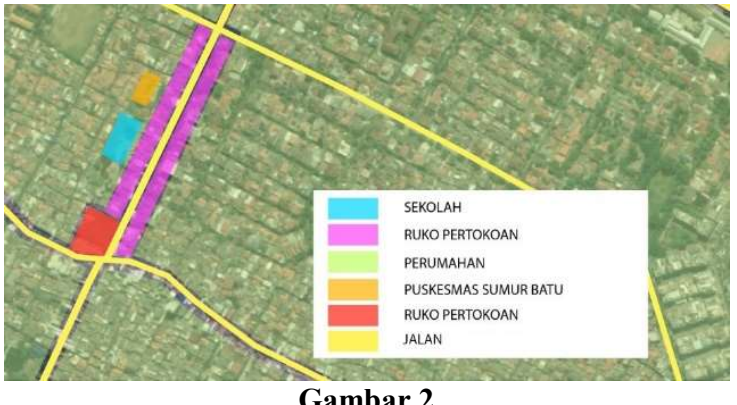

Gambar 2

Zonasi Pasar Sumur Batu

(Sumber: Google Maps dan Olah Pribadi, 2019)

Penggunaan lahan di jalan sumur batu raya inipun beragam, dimulai dari sekolah hingga ruko pertokoan. Namun, yang paling banyak mendominasi penggunaan lahan yang ada di jalan ini adalah area pertokoan. Hal inilah yang membuat pasar ini tumbuh untuk mewujudkan terbentuknya pasar sumur batu.

Kondisi yang peneliti lihat pada pasar ini adalah keberadaan pedagang kaki lima yang ramai di sepajang jalan utama ini. Pedagang kaki lima ini menempati sela sela pertokoan atau jalur pedestrian sebagai tempat berjualan. Kebutuhan ruang dan antar pedagang formal dan informal menimbulkan ruang berbagi dengan teritori yang yang tetap memperhatikan keuntungan masing-masing sektor tersebut (Prabawa \& Pratiwi, 2018). Karena banyaknya pedagang yang tumbuh kian hari lokasi ini menjadi sangat ramai dan menjadi Kawasan utama dalam berbelanja kuliner maupun peralatan rumah.

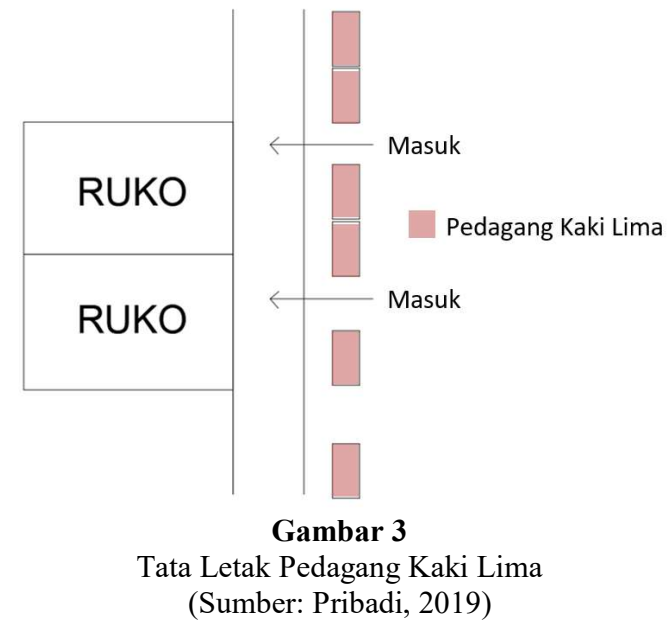

Ukuran dari tiap tenant pedagang kaki lima ini kurang lebih memiliki ukuran 1-2 meter. Bagi pedagang beserta tempat makannya memiliki ukuran 4-5 meter. Parkiran yang 
digunakan para pembeli adalah parkiran illegal yang menggunakan separuh dari jalan utama untuk menunggu proses transaksi jual beli. Pasar informal ini buka pukul 10 pagi hingga 10 malam dengan pedagang yang berbeda beda atau bergantian. Pada pagi hari hingga sore hari tidak terlalu banyak pedagang yang mana berisi pedagang helm, baju, makanan dan minuman, sehingga pada sore hari jalan ini tidak terlalu ramai dan menimbulkan kemacetan. Pada sore harinya hampir seluruh pedagang itu tutup dan digantikan dengan pedagang baru yang menjual makanan dan minuman pergantian ini membawa kepadatan yang cukup besar karena para pedagang yang datang harus menunggu pedagang yang pulang dan jalanan sudah sangat ramai dikarenakan jam pulang kerja.

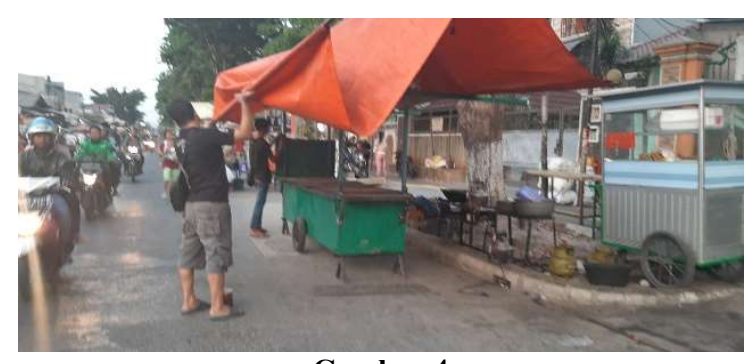

Gambar 4

Proses Pergantian Pedagang Kaki Lima (Sumber: Pribadi, 2019)

Keadaan pasar yang ramai membuat kendaraan bergerak sangat lambat dan kadang menimbulkan kemacetan. Kecepatannya yaitu sekitar $10-20 \mathrm{~m} / \mathrm{s}$. keadaan tersebut seringkali terjadi malam hari dan sore hari saat banyaknya pedagang yang ada di pasar dan pergantian para pedagang. Pasar informal ini pun berada di sela sela pasar formal karena ingin mencari keuntungan dari para pembeli yang telah selesai melakukan transaksi di ruko-ruko terdekat. Yang membuat tertarik adalah barang dagangan yang dijual yang mana hampir keseluruhan adalah makanan dan minuman yang berbedabeda.

Pasar adalah salah satu infrastruktur tempat usaha dan jasa yang mana didalamnya dapat melakukan hubungan sosial antara pedagang dengan pedagang lainnya, pedagang dengan pembeli dan pembeli dengan pembeli untuk memenuhi kebutuhan pengunjungnya dengan imbalan uang. Sehingga pasar kini menjadi suatu yang paling dicari masyarakat karena menjadi pusat penjualan barang paling terlengkap, mulai dari sembako, pakaian, makanan, dan lain-lain.

Adapun yang dilakukan pedagang dengan pembeli biasanya dengan cara transaksi barang dan jasa, dengan menggunakan uang sebagai alat tukarnya sehingga pengunjung bisa dapat barang sesuai yang diinginkan. Pasar menjadi pusat media yang paling ramai dikujungi, dan dibutuhkan masyarakat, maka dari itu perlunya fasilitas parkir yang luas, nyaman dan aman. Sehingga pengunjung bisa menikmati dengan bebas dan tidak membuat suatu kemacetan di jalan.

Pasar juga harus dikelola dengan baik dan menarik agar menjadi menjadi daya Tarik masyarakat untuk mengunjunginya sehingga tidak ada pihak yang merasa dirugikan. Terkadang hubungan sosial ekonomis yang terbangun ini dapat menumbuhkan rasa persaingan antara pedagang yang satu dengan pedagang lainnya. Namun tetap pada koridor persaingan yang sehat dengan tujuan memberikan pelayanan yang berkualitas kepada masyarakat. Oleh karena itu perlu media untuk memberikan kepuasan kepada masyarakat baik pedagang atau pembeli. Guna untuk memenuhi kepuasan pembeli maka pasar harus menampug para pedagang dengan jumlah yang banyak sehingga menampung berbagi macam produk ingin dipasarkan (Syarifuddin, 2018).

\section{Pedagang Kaki Lima}

Pedagang kaki lima atau yang disingkat (PKL) merupakan pedagang yang identik dengan menjajakan barang dan jasanya untuk dijual ke pengunjung di tepat ruang untuk kepentingan umum seperti pinggir jalan atau trotoar yang biasanya menggunakan gerobak dorong. Banyaknya pedagang kaki lima di ruang trotoar terkadang membuat dan menganggu pengguna jalan tersebut baik pengguna motor, mobil maupun pejalan kaki.

Timbulnya banyaknya pedagang kaki lima di ruang yang fungsional karena adanya keterpaksaan dan kurangnya lapangan kerja, serta peran pemerintah dalam merespon hal tersebut kurang baik, misalnya banyaknya masyarakat yang berprofesi jadi pedagang kaki lima dengan lahan terbatas pemerintah tidak memberikan wadah atau fasilitas untuk mereka melakukan kegiatan aktivitas berdagang. 
Proses urabanisasi yang berangkaian dari desa ke kota besar membuat Kawasan semakin padat penduduk dan pertumbuhan kesempatan kerja yang lambat membuat sesorang lebih memilih berwirausaha untuk memenuhi kebutuhan ekonomi keluarga (Ramadhan, 2015).

Pedagang kaki lima diartikan sebagai pedagang kecil yang menyalurkan dagangannya ke kota atau tempat yang lebih besar dengan pendapatan yang relatif rendah dan diperjual belikan ditempat tempat umum (Yusroni, 2009). Walaupun seperti itu kalangan kalangan bawah juga masih membutuhkan mereka, karena dagangan yang mereka jual lebih murah dibandingkan tempat tempat yang modern. Maka dari itu, keberadaan mereka adalah keinginan dari rakyat itu sendiri (Giyarto, 2014).

Sektor informal menggambarkan bagian angkatan kerja kota yang berada diluar pasar tenaga terorganisasi. Aktifitas-aktifitas informal tersebut merupakan cara melakukan sesuatu yang ditandai: mudah untuk dimasuki; bersandar pada sumber daya lokal; usaha milik sendiri; operasinya dalam skala kecil; padat karya dan teknologinya bersifat adaptif; keterampilan dapat diperoleh diluar sistem sekolah formal; dan tidak terkena secara langsung oleh regulasi (Kurniadi, 2016). Walaupun sektor informal khususnya pasar informal tidak disukai kehadirannya namun bagaimanapun pasar ini cukup memberi wajah kota di Indonesia (Hantono, 2019).

\section{Sirkulasi \& Zonasi Pasar}

Sirkulasi yang merupakan akses untuk mengarahkan kegiatan di dalam pasar harus direncanakan dengan benar supaya memberikan tatanan yang efektif bagi kegiatan di dalam pasar. Besaran sirkulasi utama pada pasar sesuai dengan literatur yaitu 3-4 meter dan sirkulasi sekunder memiliki besaran 1,5-2 meter. Panjang los untuk pasar mempunyai panjang $10-15$ meter serta kios 20 - 30 meter (Dewar \& Watson, 1990) (Pradhipta, Razziati, \& Handajani, 2015).
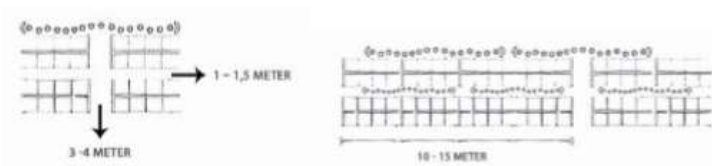

Gambar 5

Dimensi Lebar Sirkulasi Utama dan Sekunder Pasar yang Efektif

(Sumber: Dewar \& Watson, 1990)

Pengelompokan komoditas sejenis pada pasar akan memberikan dampak kesinambungan area komoditas yang terkait. Satu kesatuannya jenis komoditas dagang membuat pengunjung tidak perlu mencari kebutuhan yang sama pada area tertentu yang lainnya. Dengan pembagian zona ini dimaksudkan agar kategori berdasarkan jenis dagang dapat memudahkan penataan komoditas dan meminimalisir pergerakan para pedagang ilegal serta menghilangkan dampak pergeseran zonasi yang telah terbentuk.
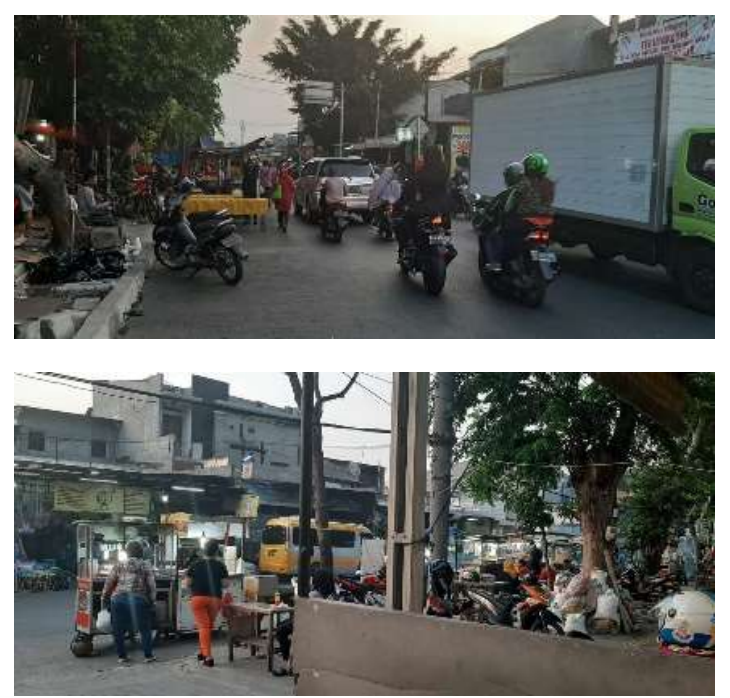

Gambar 6

Pasar Sumur Batu

(Sumber: Pribadi, 2019)

\section{Pola Pergerakan Pembeli}

Pembeli bergerak sesuai dengan hasratnya. Berbagai pembeli hadir dengan segelintir pikiran untuk memperoleh suatu barang yang dapat diraih agar dapat memuaskan kebutuhan jasmaninya. Pada kasus pasar sumur batu ini barang yang paling banyak dijual adalah kuliner yang mana terdiri dari berbagai makanan dan minuman. Ini menjadi daya tarik utama dari pasar ini untuk memperoleh pangsa pasar yang 
banyak terutama masyarakat yang mencintai budaya makanan pencuci mulut.

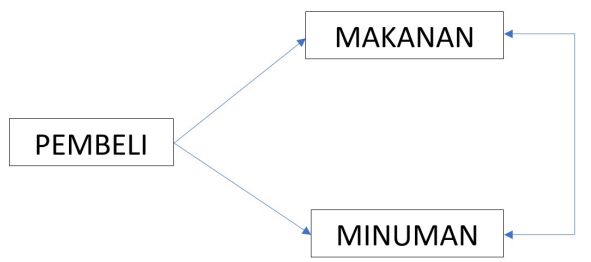

Gambar 7

Pola Pergerakan Pembeli

(Sumber: Pribadi, 2019)

Pergerakan pembeli yang dapat disimpulkan para peneliti seperti gambar di atas. Pada kasus pasar ini pembeli mempunyai target untuk membeli salah satu dari jenis dagangan yang ada di pasar ini bahkan tak jarang ada yang membeli keduanya sekaligus. Barang dagangan pertama yang dibeli oleh pembeli terkadang tidak terprediksi. Namun, apabila barang pertama sudah di beli kemungkinan barang kedua adalah pasangan dari barang pertama atau tidak dibeli sama sekali. Makanan dan minuman merupakan barang dagangan yang saling melekat. Keduanya saling dibutuhkan setiap terjadinya proses jual beli terutama di kaki lima yang menjual makanan cepat saji yang mana minuman merupakan unsur pendukung yang dibeli tiap pengujung.

\section{Pola Pergerakan Pembeli Terhadap Tata Letak Pedagang Kaki Lima di Pasar Sumur Batu}

Tata letak pedagang mempengaruhi pola pergerakan pembeli yang mana tata letak pedagang kaki lima pada malam hari dan siang hari sangatlah berbeda. Pada gambar di bawah ini disajikan tata letak pedagang pada pagi hingga sore hari adalah sebagai berikut.

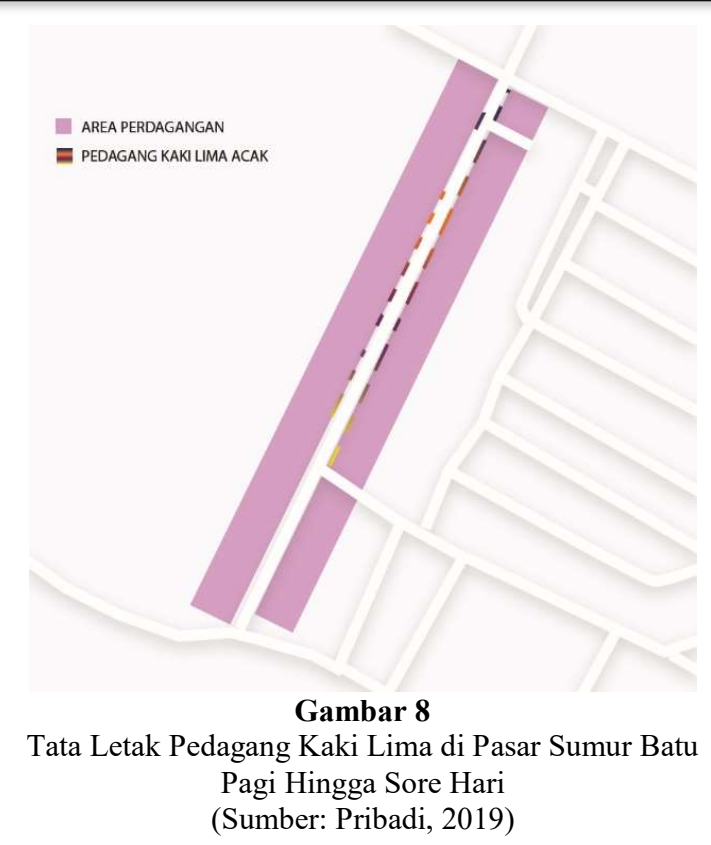

Pada pagi hingga sore hari pedagang yang ada di sepanjang jalan sumur batu jaya tidaklah terlalu banyak sehingga terjadi kelenggangan pada jalan yang ada. Barang yang dijual pada sepanjang jalan inipun juga berbeda dari barang dagangan yang dijual di malam hari. Pada pagi hingga sore hari barang dagangan yang dijual berupa makanan, minuman hingga barang kegunaan sehari hari seperti perabotan rumah tangga hingga helm kendaraan bermotor. Tata letak inipun mempengaruhi pergerakan pejalan kaki (Hantono, 2017).

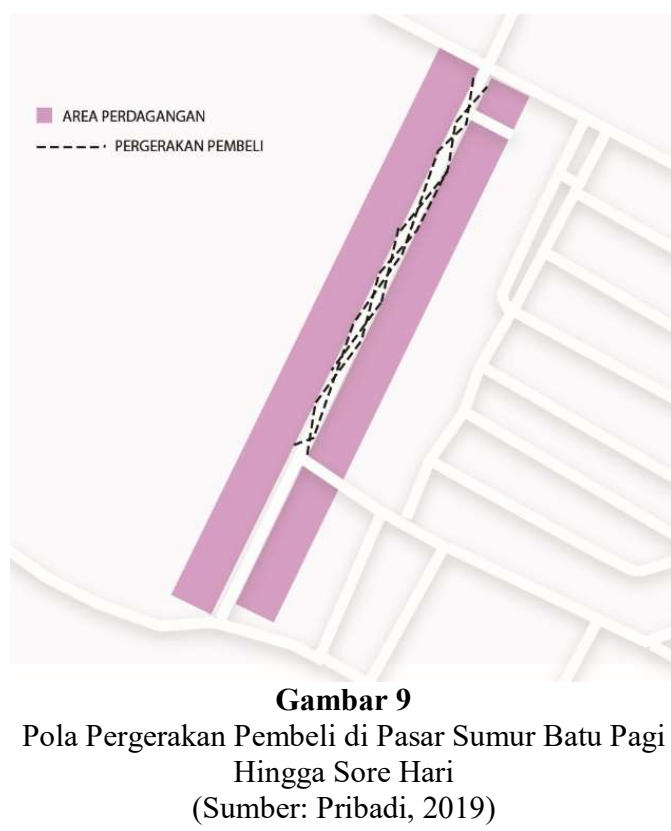


Tata letak pedagang yang acak serta keberadaan pedagang yang terbatas membuat pergerakan pembeli terjadi secara acak dan dilakukan secara personal. Pergerakan ini tanpa memikirkan keinginan untuk melihat keseluruhan penjual, karena penjual yang ada adalah penjual yang sering berjualan di lokasi tersebut dan dapat dingat karena keberadaan dagangan yang terbatas. Pergerakan ini pun berpengaruh terhadap kepadatan dari jalan sumur batu jaya hingga seperti pada gambar di bawah ini.

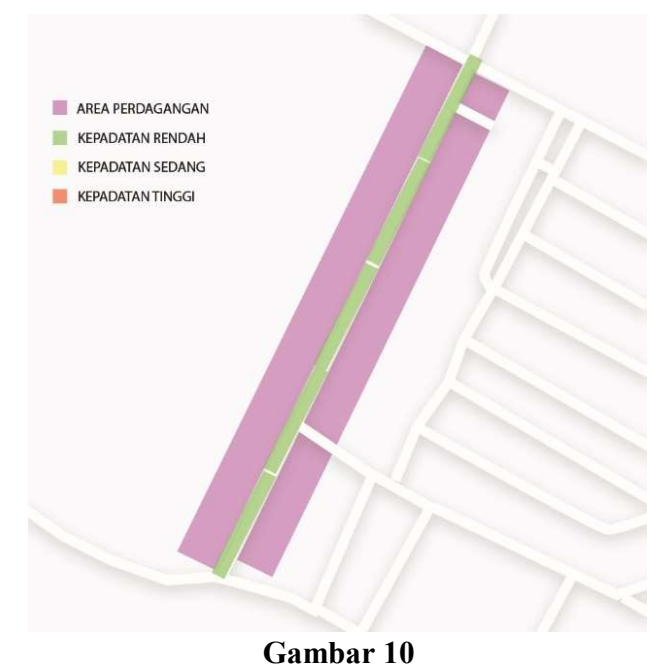

Kepadatan Jalan Pasar Sumur Batu Pagi Hingga Sore Hari

(Sumber: Pribadi, 2019)

Kepadatan yang terjadi pada pasar sumur batu ini di pagi hingga sore hari adalah kepadatan tingkat rendah. Karena pembeli yang datang tidak terlalu banyak dan langsung menuju dagangan yang diinginkannya sehingga mereka cepat pergi dan kemudian pembeli berikutnya datang kembali. Kelengangan terjadi karena pengguna jalan pada pagi hingga sore hari relatif sepi ini terjadi karena seluruh warga masih bekerja di tempat pekerjaannya masing masing sehingga jalan tersebut hanya sering dilewati oleh para pengendara yang ingin melintas bukan untuk berbelanja.

Sedangkan pada sore hingga malam hari tata letak pedagang kaki lima adalah sebagai berikut.

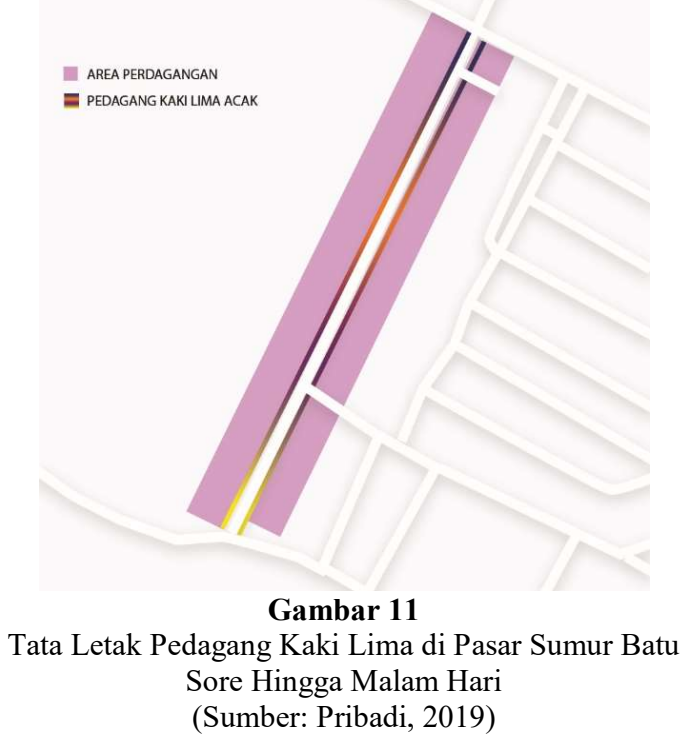

Hal ini terjadi untuk mengurangi tingkat persaingan antar pedagang serta pemerataan pedagang yang mana dari awal memasuki pasar hingga mengakhiri pasar para pedagang ini berselang seling dalam hal barang dagangannya. Hal ini juga terjadi karena tidak semua pembeli dapat memutuskan barang yang akan dibelinya dengan cepat sehingga dibutuhkan perjalanan mengelilingi pasar agar dapat melihat seluruh barang dagangan sehingga semua dagangan memiliki kesempatan untuk dilihat.

Pergerakan pembeli di pasar sumur batu ini memiliki berbagai macam Gerakan. Tetapi yang paling sering dilakukan karena pengaruh tata letak pedagang adalah seperti gambar di bawah ini.

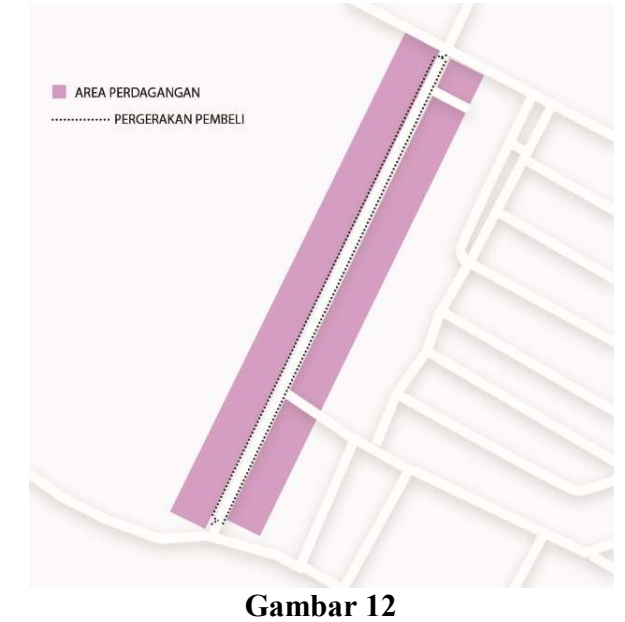

Pola Pergerakan Pembeli di Pasar Sumur Batu Sore Hingga Malam Hari

(Sumber: Pribadi, 2019) 
Pada gambar di atas dapat dikemukakan bahwa para pembeli pada malam hari dengan sengaja melewati seluruh pedagang untuk melihat seluruh jenis dagangan dan kembali lagi untuk memutuskan barang dagangan yang akan dibeli. Dengan kondisi seperti ini dapat mempengaruhi beberapa hal yang menyangkut hal fisik maupun nonfisik dari para pedagang. Dalam hal peletakan dagangan, para pedagang memutuskan untuk meletakkan barang dagangannya secara acak yaitu dimana pedagang yang berada di sampingnya merupakan pedagang dengan jenis barang yang berbeda zonasinya dapat dilihat seperti gambar di bawah ini. Pergerakan pembeli ini juga dapat mempengaruhi tingkat kepadatan pengguna jalan yang mana dapat menimbulkan kemacetan bagi para pengguna jalan lainnya zonasi kepadatannya dapat dilihat seperti pada gambar di bawah ini.

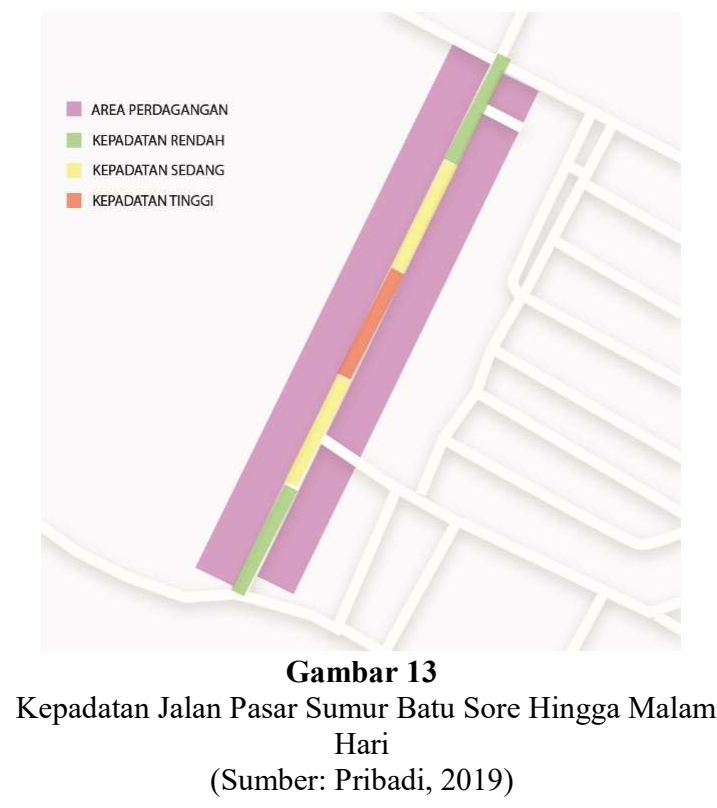

Kepadatan yang terjadi dapat menguntungkan dan juga merugikan para pedagang maupun pembeli. Keuntungan yang didapat yaitu disaat kepadatan terjadi berarti pedagang yang berada di lokasi kepadatan tersebut memiliki waktu yang banyak untuk memamerkan barang dagangannya dan para pembeli dapat berfikir berkali kali untuk memutuskan membeli atau tidaknya barang yang dilihatnya. Keuntungan juga terjadi karena disaat adanya kepadatan berarti ada barang dagangan yang sangat disukai masyarakat sehingga mereka rela untuk mengantri maupun menunggu lebih lama sehingga orang yang melewati kepadatan tersebut akan merasa heran dan ingin mencoba membelinya. Kerugian yang didapat adalah para pengguna yang tidak berniat untuk membeli makanan atau minuman merasakan kemacetan yang menguras waktu sehingga akan membuat terjadinya kebisingan di jalan tersebut. Kerugian lain didapatkan para pembeli yang ingin memarkikan kendaraannya di jalan yang didominasi oleh kepadatan, jalan tersebut akan penuh dan tidak terdapatnya parkir bagi para pembeli atau pun pemilik ruko.

\section{SIMPULAN}

Dari hasil dan pembahasan di atas dapat diambil kesimpulan berupa pola pergerakan pembeli yang dipengaruhi pedagang serta hasil zonasi pedagang yang mempengaruhi.

Pergerakan pembeli yang terjadi pada pagi hingga sore dan sore hingga malam sangatlah berbeda. Yang terjadi pada pagi hingga sore yaitu pergerakan pembeli yang terlampau acak. Ini terjadi karena keberadaan pedagang yang tidak terlalu banyak dan ketidak padatan jalan yang membuat kebebasan pembeli dalam mengakses jalan sumur batu raya. Sedangkan sore hingga malam hari pergerakan pembeli terlampau mengitari jalan. Ini terjadi karena pembeli dibuat tertarik untuk melihat seluruh dagangan yang ada dengan keberadaan pedagang yang cukup banyak dan lokasi yang kian ramai.

Menurut zonasi yang diciptakan pedagang dibuat untuk menarik perhatian tiap pembeli tiap harinya. Pada pagi hingga sore karena keberadaan pedagang yang sedikit membuat pedagang bersifat terpencar dan mudah dilihat serta di datangi sedangkan malam hari yang terlampau banyak membuat zonasi mereka dibuat secara acak agar menuntut pembeli untuk mengitari seluruh pedagang yang ada.

\section{DAFTAR PUSTAKA}

Damsar, \& Indrayani. (2018). Pengantar Sosiologi Pasar (1st ed.). Jakarta: Prenadamedia Group. 
Giyarto. (2014). Dampak yang Ditimbulkan dengan Adanya Pedagang Kaki Lima (PKL) Dipasar Legi Kota Surakarta. Rechtstaat, 8(2), 1-18. Retrieved from https://ejournal.unsa.ac.id/index.php/rech staat/article/view/91

Hantono, D. (2017). Pola Aktivitas Ruang Terbuka Publik Pada Kawasan Taman Fatahillah Jakarta. Komposisi, 11(6), 265277.

https://doi.org/10.24002/jars.v11i6.1360

Hantono, D. (2019). Pasar Informal dan Wajah Kota di Indonesia. In Antologi Kota Indonesia \#2 (pp. 131-144). Jakarta: Omah Library.

Kurniadi, I. R. (2016). Kinerja Satuan Polisi Pamong Praja Dalam Penertiban Pedagang Kaki Lima di Kota Pekanbaru. Jom FISIP, 3(1), 1-10. Retrieved from https://jom.unri.ac.id/index.php/JOMFSI $\mathrm{P} /$ article/view/8774

Prabawa, M. S., \& Pratiwi, N. M. W. (2018). Fenomena Ruang Saling Berbagi Bale Banjar Titih Sebagai Model Ruang Bermukim Perkotaan di Denpasar. Undagi, 6(2). https://doi.org/10.22225/undagi.6.2.1026. $75-81$

Pradhipta, A., Razziati, H. A., \& Handajani, R. P. (2015). Penataan Pola Tata Ruang Dalam Pasar Legi Tradisional Kota Blitar. Jurnal Mahasiswa Jurusan Arsitektur, 3(4). Retrieved from http://arsitektur.studentjournal.ub.ac.id/in dex.php/jma/article/view/167

Ramadhan, R. (2015). Perubahan SosialEkonomi PKL (Pedagang Kaki Lima ) dalam Program Sentralisasi Sektor Informal Perkotaan di DTC Wonokromo. Komunitas, 4(3).

Syarifuddin, D. (2018). Pasar Tradisional dalam Perspektif Nilai Daya Tarik Wisata. Jurnal Manajemen Resort \& Leisure, 15(1), 19-32. https://doi.org/10.17509/jurel.v15i1.1126 6
Yusroni, N. (2009). Keberadaan Pedagang Kaki Lima Sebagai Unsur Pembentuk Kegiatan Fungsional Kota. Akses: Jurnal Ekonomi Dan Bisnis, 4(7), 66-72. https://doi.org/10.31942/akses.v4i7.515 